\title{
Deoxyhypusine Synthase
}

National Cancer Institute

\section{Source}

National Cancer Institute. Deoxyhypusine Synthase. NCI Thesaurus. Code C30016.

Deoxyhypusine synthase (369 aa, $41 \mathrm{kDa}$ ) is encoded by the human DHPS gene. This protein plays a role in the synthesis of deoxyhypusine and the post-translational modification of the eukaryotic translation initiation factor 5A-1 protein. 